\title{
Right coronary artery pseudoaneurysm post everolimus eluting stent implantation causing tamponade
}

\author{
Niraj Nirmal Pandey, Arun Sharma, Sanjeev Kumar
}

Department of Cardiovascular Radiology and Endovascular Interventions, All India Institute of Medical Sciences, New Delhi, India

\section{Correspondence to} Dr Niraj Nirmal Pandey, nirajpandey2403@gmail.com

Accepted 1 October 2018

\section{DESCRIPTION}

A 49-year-old man with triple vessel coronary artery disease underwent percutaneous coronary intervention. The right coronary artery (RCA) was treated with two platinum chromium everolimus-eluting stents (Promus Stent; Boston Scientific, Natick, Massachusetts, USA); $3.5 \times 16 \mathrm{~mm}$ in proximal RCA and $3.5 \times 38 \mathrm{~mm}$ in mid-to-distal RCA, respectively, with stenting of the left anterior descending (LAD) artery and first obtuse marginal artery (OM1) as well.

The patient was readmitted a month later with chest pain and dyspnoea on exertion. On examination, the patient had tachycardia, elevated jugular venous pressures and mild hypotension. A catheter angiogram revealed a small pseudoaneurysm arising from the RCA with occluded mid RCA stent. In view of disproportionately severe symptoms compared with the size of the pseudoaneurysm and to delineate the anatomy of the pseudoaneurysm for planning management, a coronary CT angiography (CTA) was advised.

CTA revealed patent proximal RCA stent, with near occlusion of the RCA just proximal to the mid RCA stent (figure 1A). A small pseudoaneurysm was seen arising at the level of proximal $1 / 3 \mathrm{rd}$ of the second stent, with a large surrounding haematoma in the atrioventricular groove (figure 1A-D). The stent showed in-stent total occlusion, with reformation of distal RCA and a good-sized posterior descending artery. Mass effect was noted on the right atrium (RA) and right ventricle with dilated RA and inferior vena cava with flattening of the interventricular septum, indicating localised tamponade (figure $1 \mathrm{~B}, \mathrm{C}$ ). The LAD and OM1 stents were patent. The patient underwent surgery with repair of the RCA pseudoaneurysm using direct pledgeted sutures and had an uneventful post-operative course.

Coronary artery pseudoaneurysms can develop from 1 week to 4 years after drug-eluting stent (DES) implantation. ${ }^{1}$ The postulated underlying mechanisms include antiproliferative and antimetabolite action of the drug and inflammatory response to the drug, the polymer or the stent platform which results in incomplete endothelialisation and poor wound healing. ${ }^{1}$ Thus, a combination of initial injury induced by stent placement and the biological response to DES might be the cause behind pseudoaneurysm formation. These pseudoaneurysms may rapidly enlarge leading
Check for updates

(C) BMJ Publishing Group Limited 2018. No commercial re-use. See rights and permissions. Published by BMJ.

\footnotetext{
To cite: Pandey NN,

Sharma A, Kumar S. BMJ Case Rep Published Online First: [please include Day Month Year]. doi:10.1136/bcr-2018227714
}

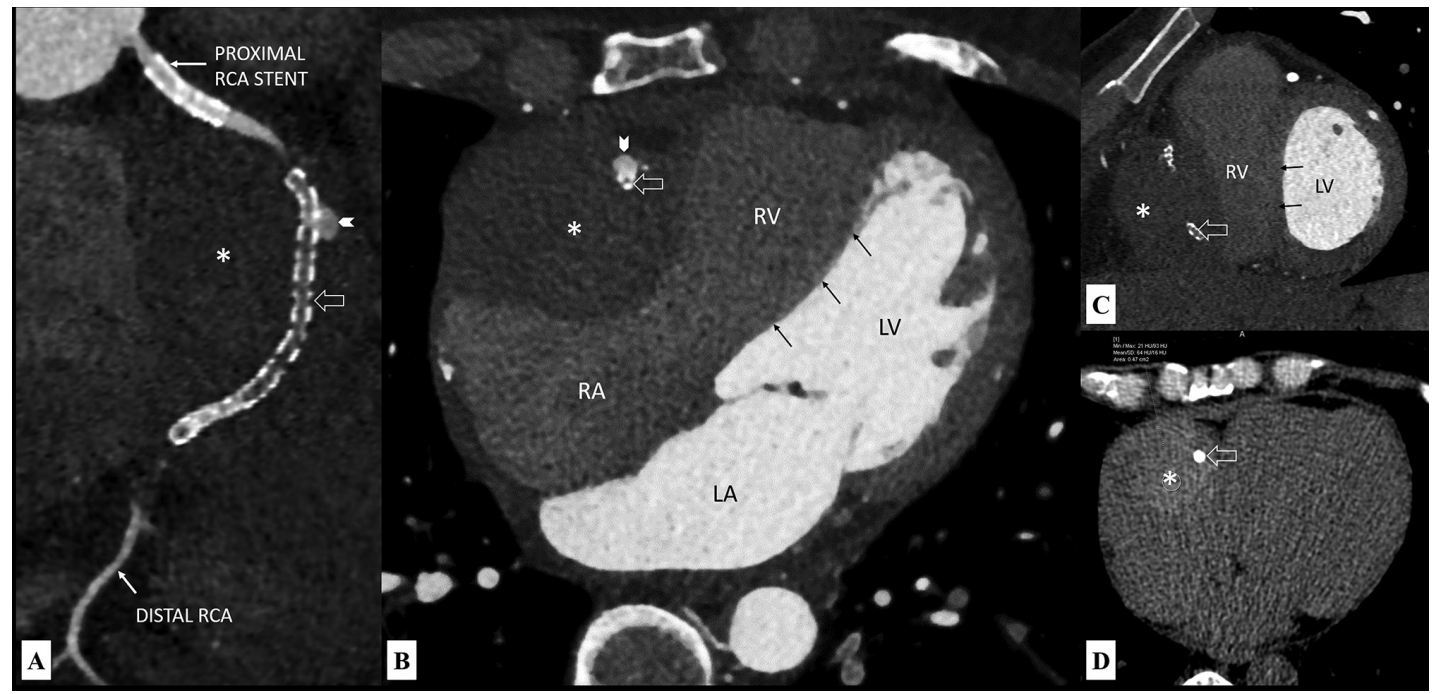

Figure 1 Curved multiplanar reformatted image of coronary CT angiography $(A)$ depicts the patent proximal right coronary artery (RCA) stent with near occlusion of the RCA just proximal to the mid-RCA stent and total in-stent occlusion of the mid-RCA stent (block arrow). A small pseudoaneurysm (white arrowhead) is seen arising at the level of proximal one-third of the second stent, with a large surrounding haematoma $\left({ }^{*}\right)$. Reformation of distal RCA is also noted. Four chamber (B) and short axis view (C) reconstructed images show the pseudoaneurysm (white arrowhead) adjacent to the RCA stent (block arrow) with adjacent haematoma $\left(^{*}\right)$ seen indenting the right atrium and right ventricle with flattening of interventricular septum (black thin arrows) to the left side. Non-contrast axial CT image (D) shows the hyperdense haematoma $\left(^{*}\right)$ (mean attenuation $\sim 64 \mathrm{HU}$ ) in the right atrioventricular groove surrounding the stent (block arrow). Abbreviations: LA, left atrium; LV, left ventricle; RA, right atrium; RV, right ventricle. 
to rupture and can rarely also cause cardiac tamponade, as was observed in this case. ${ }^{2}$

\section{Learning points}

Coronary artery pseudoaneurysms can develop from 1 week to 4 years after drug-eluting stent implantation.

- A combination of initial injury induced by stent placement and the biological response to drug-eluting stent, including antiproliferative and antimetabolite action of the drug and inflammatory response to the drug, the polymer, or the stent platform, might result in pseudoaneurysm formation.

- Coronary artery pseudoaneurysms may rapidly enlarge leading to rupture and can rarely cause cardiac tamponade.
Contributors NNP, AS and SK have participated sufficiently in the conception of the idea, development of the intellectual content, design, writing and final approval of the manuscript.

Funding The authors have not declared a specific grant for this research from any funding agency in the public, commercial or not-for-profit sectors.

Competing interests None declared.

Patient consent Obtained.

Provenance and peer review Not commissioned; externally peer reviewed.

\section{REFERENCES}

1 Aoki J, Kirtane A, Leon MB, et al. Coronary artery aneurysms after drug-eluting stent implantation. JACC Cardiovasc Interv 2008;1:14-21.

2 Hori D, Noguchi K, Nomura Y, et al. Enlarged coronary artery pseudoaneurysm after drug-eluting stent implantation. Asian Cardiovasc Thorac Ann 2013:21:608-11.

Copyright 2018 BMJ Publishing Group. All rights reserved. For permission to reuse any of this content visit http://group.bmj.com/group/rights-licensing/permissions.

BMJ Case Report Fellows may re-use this article for personal use and teaching without any further permission.

Become a Fellow of BMJ Case Reports today and you can:

- Submit as many cases as you like

- Enjoy fast sympathetic peer review and rapid publication of accepted articles

- Access all the published articles

Re-use any of the published material for personal use and teaching without further permission

For information on Institutional Fellowships contact consortiasales@bmjgroup.com

Visit casereports.bmj.com for more articles like this and to become a Fellow 